\title{
Going Dutch? Lessons from the Outcome-Based Political Science Curriculum in the Netherlands
}

\author{
Marijke Breuning, University of North Texas
}

ABSTRACT Dutch political science curricula integrate the acquisition of knowledge of the discipline and transferable skills. This makes it an interesting case for US political science education, especially in light of Wahlke's (1991) recommendations for a structured political science curriculum that incorporates skills training in addition to knowledge of the field. Although some of Wahlke's recommendations were widely adopted, US political science curricula remain relatively loosely structured and often do not explicitly focus on transferable skills.

This article argues that the Dutch example may help US programs revisit how to best achieve learning outcomes that allow students to acquire both knowledge and transferable skills. This is not an argument for "going Dutch" wholesale; instead, the article suggests modest modifications to US political science curricula.

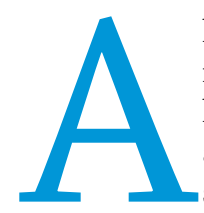

lmost three decades ago, Wahlke (1991) recommended a structured political science curriculum that included a focus on transferable skills as well as expertise in the discipline. Although some of his recommendations are visible in political science education in the United States today, most degree programs remain relatively loosely structured (Adelman 2008; AACU 2017; Breuning, Parker, and Ishiyama 2001; Gaston 2008; Ishiyama 2005; Szarejko and Carnes 2018). In contrast, European higher education has developed recommendations and outcome statements as part of the Bologna Process (Reinalda 2008a; 2008b; Roper 2007). There is variation in enthusiasm for-and implementation of-the various recommendations (Adelman 2008). However, Dutch political science programs have been at the forefront of their implementation (Nölke 2005).

This makes the Dutch programs interesting for US political science, which is poised to revisit the structure and objectives of the major. Which aspects of the Dutch curriculum might be usefully adapted? Which aspects would not fit well in US higher education? After describing the European and national influences on the development of the outcome-driven Dutch curricula, as well as outlining key features of these programs, the article addresses whether-and in what form-these ideas could benefit political science education in the United States.

Marijke Breuning $(\mathbb{D}$ is professor of political science at the University of North Texas. She can be reached at marijke.breuning@unt.edu.

\section{THE BOLOGNA PROCESS AND EUROPEAN HIGHER} EDUCATION

Dutch political science education has been influenced by the Europe-wide Bologna Process, which led to the creation of the European Higher Education Area (EHEA) that currently includes 48 countries (EHEA 2017). The Bologna Process seeks to (1) make it easier for students to find employment anywhere in Europe after graduation by establishing mutual recognition of diplomas; and (2) facilitate the mobility of students. To achieve this, it sought to create common structures for degree programs, a common credit system (i.e., the European Credit Transfer System [ECTS]), and shared outcome statements (i.e., the Dublin Descriptors) (EHEA 2017). It also worked to strengthen qualityassurance mechanisms (EHEA 2017).

The Bologna Process relies on so-called soft law, which entails a focus on standard setting rather than European-level legislation (Reinalda 2008a; 2008b). Not all participating countries have made equal progress. Indeed, in some countries, there is significant debate about the merits of the Bologna Process (Grove 2012; Meny 2008; Pechar 2012; Scott 2012).

Dutch political science programs, however, have made important strides in adapting their curricula to these Europewide standards. They have done this in part because the Dutch government mandated it (Nölke 2005). The national accreditation agency, the Nederlands-Vlaamse Accreditatie Organisatie (NVAO) (Accreditation Organization of the Netherlands and Flanders), employs stringent standards informed by the Bologna Process. Universities-and programs-must meet these standards 
to maintain their accreditation. Assessment occurs in a six-year cycle. All political science programs are evaluated simultaneously to provide comparative perspective. The universities propose and the NVAO approves a panel of experts, which is supported by an NVAO-trained independent professional throughout the evaluation process. The panel rates each bachelor's and master's program separately on the basis of applicable NVAO standards. Programs either are reaccredited, asked to remedy problems, or have reaccreditation withheld. In the latter case, the program loses its public funding and is closed; this is rare. However, continued accreditation is not guaranteed, and programs may be asked to prepare a plan for the implementation of improvements. In this case, the program will be reevaluated after two years and can receive its reaccreditation if the problems have been addressed satisfactorily.
The three-year bachelor's degree program encompasses 180 credits in the ECTS. 3 The ECTS predates the Bologna Process and originally was designed to facilitate credit transfer among European universities (Adelman 2008; Roper 2007). However, it is now also used as a credit-accumulation system in the EHEA.

Roper (2007) explained that the system works differently from the US credit system. The latter is based on "contact hours," generally measured in terms of the number of hours per week that a course meets. In contrast, the ECTS estimates the average time it takes to achieve required learning outcomes. It counts the time a student spends not only in class but also on tasks such as reading, writing, and studying. Several Dutch universities state explicitly that one European Credit (EC) requires about 28 hours of studying. ${ }^{4}$ Students are expected to complete the bachelor's degree (i.e., 18o ECs) in three years, completing

\section{Dutch political science programs, however, have made important strides in adapting their curricula to these Europe-wide standards.}

Political science degrees are offered at four universities in the Netherlands: Radboud University Nijmegen, University of Amsterdam, Vrije Universiteit Amsterdam, and Leiden University. Several other universities offer related, interdisciplinary programs, which are not included here. ${ }^{1}$

In contrast with the United States, a bachelor's degree (or equivalent) traditionally was not recognized as a university degree in the Netherlands (as elsewhere in Europe). Students typically completed (the equivalent of) a master's degree. In 2002, the Bologna Process led to the government-mandated introduction of separate bachelor's and master's degrees. However, Dutch university students generally still complete a master's degree before seeking employment. Therefore, both degrees are discussed.

\section{STARTING WITH OUTCOMES}

Dutch political science education at the bachelor's and master's levels is guided by outcome statements based on the Qualifications Framework of the EHEA, which was adopted in 2005. It is better known as the Dublin Descriptors. According to the European Consortium for Accreditation (ECA 2014), the Dublin Descriptors are "generic statements of typical expectations of achievements and abilities" associated with the completion of a bachelor's or master's degree. They apply generally across the disciplines. The Dublin Descriptors delineate competence levels for both the bachelor's and the master's degrees and include five components: (1) knowledge and understanding; (2) application of knowledge and understanding; (3) making judgments; (4) communication; and (5) lifelong learning skills (ECA 2014). ${ }^{2}$

In the Netherlands, these generic descriptors were adapted to political science through a process of consultation among the four political science departments. This process was built on agreements that the European Conference of National Political Science Associations made in 2003 and involved the Landelijk Overleg Opleidingen Politicologie (LOOP) (National Consultation of Political Science Programs).

The European agreements address both the duration and the content of political science programs (Reinalda 2008a; 2008b).
60 credits annually or 30 per semester. A Dutch semester is 20 weeks long. Hence, full-time study, on average, is equivalent to a 40 -hour workweek. ${ }^{5}$ US universities usually translate 1 EC into a half credit (Roper 2007).

The European agreements that set the bachelor's degree at 18o ECs also determined that at least 90 ECs should involve political science courses. Dutch political science bachelor's degree programs all exceed that minimum requirement. This differs from US bachelor's degrees, which typically require 30 to 36 credit hours in the major discipline (of a total 120 for a four-year degree).

Additionally, the European agreements specified that a bachelor's degree program in political science must include coursework in the following subfields: (1) political theory; (2) quantitative and qualitative methods; (3) the political system of one's own country and the European Union; (4) comparative politics; and (5) international relations (see the Nijmegen bachelor's degree self-study appendix; Reinalda 2008b).

Furthermore, Dutch master's degree programs are one year or 6o ECs. ${ }^{6}$ Because university education traditionally is regarded as completed only after attaining the (equivalent of) master's degree, most students enroll in such a program after completing the bachelor's degree.

Dutch political science programs adhere to the European agreements not only in length and content; they also have adapted the Dublin Descriptors to outcomes for political science. These outcome statements are listed in table 1, which is organized in terms of the Dublin Descriptors' five components and outlines competence levels associated with the bachelor's and master's degrees. The table shows how (1) outcome statements provide discipline-specific versions of the Dublin Descriptors; and (2) competence levels for the master's degree build on-and differ from-those for the bachelor's degree.

Competence levels for each degree combine knowledge and skills. Students must acquire discipline-specific knowledge as well as transferable skills.7 The latter are skills that, although gained in the context of studying political science, can be applied in a variety of settings. 
Each of the four Dutch universities that offer political science degrees uses these outcome statements as the foundation for its curriculum. The next section describes their program features.

\section{DUTCH POLITICAL SCIENCE CURRICULA}

In contrast to the United States, where students typically take five courses simultaneously that last the entire 15 weeks of the semester, Dutch universities split their 20-week semesters into
Students are expected to follow the prescribed sequence to achieve cumulative learning outcomes. Each university offers a variation of this common model. Appendix table 2 illustrates this through the allocation of credit hours to the different elements of each university's curriculum.

Radboud University Nijmegen offers a fully structured set of courses, whereas the University of Amsterdam allocates almost half of the substantive knowledge courses to specialization electives. Furthermore, there is variation in the ECs allotted to

\section{Dutch political science programs adhere to the European agreements not only in length and content; they also have adapted the Dublin Descriptors to outcomes for political science.}

several blocks, the length of which varies among the universities. Most courses are taught in these shorter blocks. Depending on the number of blocks into which a semester is split, students take two or three courses simultaneously. In addition, the number of ECs earned can vary. The default is 6 ECs ( 5 ECs at Leiden University), but some courses are as many as 9 ECs or as few as 2 or 3 ECs. The following sections discuss the Dutch bachelor's and master's degree programs in further detail.

\section{The Bachelor's Degree Program}

Each political science program offers a structured and sequenced curriculum that starts with introductory-level courses and builds across the three years to more difficult and specialized material. research methods and professional skills. The explicit focus on the latter helps students to understand that they are acquiring valuable competencies for future careers.

There is much less emphasis on free electives and required support than what is common in the United States. The required support also is quite structured, with each university requiring specific courses in two or three cognate fields (see appendix table 3). The free electives are clustered in one semester so that students can study abroad or complete an internship. Required support and free electives constitute only between $17 \%$ and $27 \%$ of the total 180 ECs. The curriculum at Dutch universities, as is common across Europe, tends to be focused on developing expertise in one discipline.

Table 1

Outcome Statements for Bachelor's- and Master's-Level Education (Dutch National Agreements Based on Europe-Wide Agreements and the Dublin Descriptors)*

\begin{tabular}{|c|c|c|}
\hline & Bachelor's Degree & Master's Degree \\
\hline \multirow{2}{*}{$\begin{array}{l}\text { Knowledge and understanding } \\
\text { of the discipline }\end{array}$} & \multirow{2}{*}{$\begin{array}{l}\text { Sufficient knowledge of recent developments } \\
\text { in the discipline to arrive at scientifically } \\
\text { supported judgments }\end{array}$} & The ability to integrate knowledge and address complex issues \\
\hline & & $\begin{array}{l}\text { Understanding the specific place of political science among other } \\
\text { sciences }\end{array}$ \\
\hline \multirow[t]{3}{*}{$\begin{array}{l}\text { Application of knowledge and } \\
\text { understanding }\end{array}$} & $\begin{array}{l}\text { Ability to process disciplinary knowledge; } \\
\text { application of knowledge to phenomena that } \\
\text { were addressed in the bachelor's degree } \\
\text { curriculum }\end{array}$ & $\begin{array}{l}\text { Ability to process information from disciplines relevant to political } \\
\text { science and apply this to political science problems; application of } \\
\text { knowledge to phenomena that were not explicitly addressed in the } \\
\text { master's degree curriculum }\end{array}$ \\
\hline & $\begin{array}{l}\text { Ability to recognize and analyze social } \\
\text { problems from the perspective of political } \\
\text { science }\end{array}$ & $\begin{array}{l}\text { Ability to recognize and analyze complex societal problems and } \\
\text { to evaluate solutions to these problems from the perspective of } \\
\text { political science }\end{array}$ \\
\hline & $\begin{array}{l}\text { Competence in devising and sustaining } \\
\text { arguments and solving problems within the } \\
\text { field of study }\end{array}$ & $\begin{array}{l}\text { Ability to offer an original contribution to address societal } \\
\text { problems }\end{array}$ \\
\hline \multirow{2}{*}{$\begin{array}{l}\text { Ability to form judgments and } \\
\text { to reflect on the discipline and } \\
\text { social phenomena }\end{array}$} & $\begin{array}{l}\text { Ability to evaluate the merits of the design } \\
\text { and results of empirical research }\end{array}$ & $\begin{array}{l}\text { Ability to evaluate the merits of the design and results of empirical } \\
\text { research, including its methodological and technical aspects }\end{array}$ \\
\hline & $\begin{array}{l}\text { Sufficient knowledge of normative theories } \\
\text { to recognize the value-laden nature of both } \\
\text { scientific theories and planned policies }\end{array}$ & $\begin{array}{l}\text { Comprehensive knowledge of normative theories to substantiate } \\
\text { a position in debates regarding the value-laden nature of both } \\
\text { scientific theories and planned policies }\end{array}$ \\
\hline Communications skills & $\begin{array}{l}\text { Ability to communicate information, ideas, } \\
\text { and solutions }\end{array}$ & $\begin{array}{l}\text { Ability to communicate scientific knowledge unambiguously, } \\
\text { including the research design as well as the motives and } \\
\text { considerations underlying it; participation in scientific and public } \\
\text { debate }\end{array}$ \\
\hline Research skills & $\begin{array}{l}\text { Knowledge of the entire empirical research } \\
\text { process through guided participation in all } \\
\text { stages of scientific inquiry }\end{array}$ & $\begin{array}{l}\text { Ability to independently formulate and execute scientific research } \\
\text { and report its results }\end{array}$ \\
\hline
\end{tabular}


Last, all students complete a thesis. This thesis serves as both a demonstration of the knowledge and skills that a student has accumulated and evidence that the program achieves the intended Dublin Descriptor-based learning outcomes. ${ }^{8}$

\section{The Master's Degree Program}

Most students complete the one-year (or 6o ECs) master's degree program immediately after obtaining the bachelor's degree. This is a remnant of the past, when students did not receive a degree until they completed the equivalent of the master's. Dutch students and employers still do not regard the bachelor's as a standalone degree-although this may change in the future.

The introduction of the two-degree structure now makes it possible for students to move to another university after completing their bachelor's degree. Students increasingly do this to pursue a specialization that is available only at another university.

The master's degree programs build on the knowledge and skills acquired during the bachelor's degree but are more focused and specialized. The four Dutch universities differ in the number and type of specializations they offer, the degree of structure, and the emphasis on additional training in research methods (see appendix table 4 ).

It is important that the master's degree curriculum moves students from passive to active engagement with the scientific endeavor. This conforms to expectations for the master's degree expressed in the Dublin Descriptors. It is most evident in the expectation that students work more independently on the design and execution of their thesis research project.

Dutch master's programs are demanding, especially considering that they are designed to be completed in one year-per the European guidelines. These programs are manageable because the bachelor's degree programs are structured and provide extensive training in research methods. However, completing the master's degree in one year requires focus, efficiency, and hard work.

\section{COMPARING DUTCH AND US POLITICAL SCIENCE} EDUCATION

The four Dutch political science bachelor's and master's programs are guided by the Bologna Process as a result of demands
Second, coursework in political science usually is moderately structured in the United States. Despite significant variation among universities, bachelor's degree programs typically entail an introductory course, a course in US government, and one in research methods; and the requirement that students must sample from the various discipline subfields as well as a capstone course. Although there are exceptions (Breuning, Parker, and Ishiyama 2001), most programs are not sequenced, which impedes the cumulation of knowledge and skills.

Master's degree programs, in contrast, often are quite structured at US universities, although not more so than in the Netherlands. Important differences are that US students enter their master's degree program with less training in research-related skills and they complete a two-year program. Important also is that in the United States, the bachelor's degree traditionally has been viewed as a complete degree. Only highperforming students with specific interests in research and additional skill-building continue to the master's degree-and possibly the $\mathrm{PhD}$.

\section{DUTCH LESSONS FOR US POLITICAL SCIENCE EDUCATION?}

What, if anything, could US political science education learn from the outcome-based curricula in the Netherlands? Although the latter produces excellent learning outcomes-as evidenced by the quality of the students' theses-US universities would find it difficult to implement curricula that closely mirror the Dutch curricula. This is due to distinct differences in the types of students that Dutch and US universities serve. The former primarily educate students who enter university after completion of their high school education. In contrast, many US universities educate a more diverse student population. Along with "traditional" students who enter after completing high school, US universities increasingly enroll students who first completed a two-year degree, accumulated credits while serving in the military, or have gaps in their education for financial or other reasons. In other words, US universities must frequently accommodate students who have accumulated credits elsewhere, which has implications for curriculum design, especially for the bachelor's degree.

\section{... US universities would find it difficult to implement curricula that closely mirror the Dutch curricula.}

of the Dutch government and the national accreditation agency (i.e., NVAO), as described previously.

US universities face a different set of incentives. Different regions of the country have their own accreditation bodies, and there is no US equivalent to the Bologna Process or EHEA. Wahlke's (1991) recommendations were not binding, although they influenced curriculum design at many US universities.

US bachelor's and master's degree programs differ from their Dutch counterparts in other respects as well. First, US bachelor's degree programs in political science are four-year degree programs, require proportionally fewer credit hours in the discipline, and provide broader exposure to the liberal arts. Dutch bachelor's degree programs leave little room for exploration beyond the chosen major.
That said, the explicit focus on both skills and knowledge outcomes in the Netherlands yields graduates who are confident in what they can offer an employer. Political science programs at US universities might consider how they also can offer students the confidence that comes from this focus, which can be accomplished without fully adopting the Dutch strict structure and sequencing.

For instance, it may be feasible to ensure that transferable skills are more explicitly integrated into the overall curriculum. Elements of these skills are routinely incorporated into political science courses in the United States, but they rarely are advertised as professional-skills training. Individual instructors require students to complete various writing, speaking, and presentation assignments. By explicitly labeling these exercises as professionalskills training, instructors not only better convey why students 
are required to complete the assignments; they also raise their awareness of the fact that they are acquiring transferable skills.

Furthermore, training in research methods is a marketable skill. It may not be feasible to offer additional methods courses in the context of US bachelor's degree programs; however, existing methods training could be better integrated into the overall curriculum. One strategy is to make the research methods course a prerequisite for upper-division distribution requirements or electives. This makes it possible to use exercises and projects to reinforce and extend a student's grasp on the research methods that are already part of most undergraduate political science programs. These modifications would require coordination and perhaps modest changes to existing bachelor's degree curricula. The result would be twofold: students would more consistently receive a full range of transferable skills training, including stronger reinforcement of research skills, and they would gain better awareness of the transferableand marketable-skills that they acquire as they complete their bachelor's degree.

\section{CONCLUSION}

It is unlikely that US political science programs can afford to be as thoroughly structured and sequenced as Dutch programs. This is due to the more diverse educational trajectories of their students, as well as the stronger focus in the United States on broader exposure to the liberal arts-as opposed to a narrower focus on the major in the Netherlands and much of Europe. However, targeted but modest modifications may allow US universities to offer students the benefits of a more explicit focus on transferable skills for employment.

\section{SUPPLEMENTARY MATERIAL}

To view supplementary material for this article, please visit https://doi.org/10.1017/S1049096519002208

\section{NOTES}

1. These are the University of Groningen's English-language bachelor's degree program in international affairs and international organization; Maastricht University's bachelor's degree program in European Studies (also in English); Utrecht University's interdisciplinary bachelor's and master's degrees in public administration and organizational science; the University of Twente's interdisciplinary degree that combines public administration and European studies; and Erasmus University Rotterdam's master's degree in sociology with an emphasis on politics and society. Additionally, the Institute for Social Studies in The Hague is affiliated with Erasmus University and offers several interdisciplinary master's degrees, including the international Mundus Master of Arts in Public Policy.

2. The Dublin Descriptors also include a competence level for the $\mathrm{PhD}$ program. However, only the bachelor's and master's degrees are discussed here.

3. Dutch-and most European-university students will have completed a rigorous high school curriculum that is somewhat equivalent to the International Baccalaureate. Dutch universities do not have general-education requirements; students focus primarily on their major field of study.

4. See Radboud University Nijmegen, available at www.ru.nl/opleidingen/bachelor/ politicologie/studieprogramma; University of Amsterdam, available at www.uva $\mathrm{nl} /$ programmas/bachelors/politicologie/studieprogramma/studieprogramma. html; or Vrije Universiteit Amsterdam, available at https://bachelors.vu.nl/nl/ opleidingen/politicologie/index.aspx.
5. This is how Leiden University describes the workload for the bachelor's degree program. Available at www.universiteitleiden.nl/onderwijs/opleidingen/bachelor/ politicologie/over-de-opleiding/studieprogramma.

6. There also are two-year research master's degree programs. These programs are highly selective and tend to enroll only those students who will continue on to doctoral study-that is, most students complete the one-year master's degree.

7. The skills training of Dutch political science programs is based not only on the Dublin Descriptors but also on consultation with employers and alumni. Hence, the programs understand the needs of employers through direct consultation as well as a result of surveys of their alumni to evaluate whether they felt well equipped in the initial stages of their career. Programs are adapted on the basis of this feedback.

8. The author reviewed a selection of both bachelor's and master's degree theses from each university. The theses serve as evidence that the program achieves the intended outcomes for reaccreditation purposes.

\section{REFERENCES}

Adelman, Clifford. 2008. The Bologna Club: What US Higher Education Can Learn from a Decade of European Reconstruction. Washington, DC: Institute for Higher Education Policy.

Association of American Colleges and Universities (AACU). 2017. The LEAP Challenge: Education for a World of Unscripted Problems. Washington, DC: AACU. Available at www.aacu.org/leap-challenge.

Breuning, Marijke, Paul Parker, and John Ishiyama. 2001. “The Last Laugh: Skill Building through a Liberal Arts Political Science Curriculum.” PS: Political Science \& Politics 34 (3): 657-61.

European Consortium for Accreditation (ECA). 2014. "Dublin Descriptors." Available at http://ecahe.eu/w/index.php/Dublin_Descriptors.

European Higher Education Area (EHEA). 2017. "European Higher Education Area and the Bologna Process." Available at www.ehea.info.

Gaston, Paul L. 2008. "Bologna, A Challenge for Liberal Education and an Exceptional Opportunity." Liberal Education 94 (4): 14-19.

Grove, Jack. 2012. "Bologna Not to Taste of German Critics." Times Higher Education Supplement. Available at www.timeshighereducation.com/news/bologna-not-totaste-of-german-critics/419845-article.

Ishiyama, John. 2005. "Examining the Impact of the Wahlke Report: Surveying the Structure of the Political Science Curricula at Liberal Arts and Sciences Colleges and Universities in the Midwest." PS: Political Science \& Politics 38 (1): 71-75.

Meny, Yves. 2008. "Higher Education in Europe: National Systems, European Programmes, Global Issues. Can They Be Reconciled?” European Political Science 7 (3): 324-34. Available at doi:10.1057/eps.2008.26.

Nölke, Andreas. 2005. "Alternatives within 'Bologna': Strategic Choices for the Design of BA/MA Programmes in Political Science." European Political Science 4 (1): 69-78. Available at doi:10.1057/palgrave.eps.2210007.

Pechar, Hans. 2012. "What Explains the Strong Resistance to Bologna in Austria and Germany?" In European Higher Education at the Crossroads: Between the Bologna Process and National Reforms, ed. Adrian Curaj, Peter Scott, Lazar Vlasceanu, and Lesley Wilson, 613-30. Dordrecht: Springer.

Reinalda, Bob. 2008a. “The Ongoing Bologna Process and Political Science.” European Political Science 7 (3): 382-93. Available at doi:10.1057/eps.2008.16.

Reinalda, Bob. 2008b. "The Bologna Process and Its Achievements in Europe 1999-2007." Journal of Political Science Education 4 (4): 463-76. Available at doi:10.1080/15512160802414012.

Roper, Steven D. 2007. "European Education Reform and Its Impact on Curriculum and Admissions: Implications of the Bologna Process on United States Education." Journal of Political Science Education 3 (1): 51-6o.

Scott, Peter. 2012. "The Bologna Process Has Been Key to European Universities' Success." The Guardian. Available at www.theguardian.com/education/2012/ apr/3o/bologna-process-key-european-university-success

Szarejko, Andrew A., and Matthew E. Carnes. 2018. "Assessing an Undergraduate Curriculum: The Evolving Roles of Subfields, Methods, Ethics, and Writing for Government Majors." PS: Political Science \& Politics 51 (1): 178-82. Available at doi:10.1017/S1049096517001901.

Wahlke, John C. 1991. "Liberal Learning and the Political Science Major: A Report to the Profession." PS: Political Science \& Politics 24 (1): 48-6o. 